\title{
Managing Market Marginalization of Smallfarmers: An Ethnographic Study
}

\author{
Thomas Amirtham ${ }^{1}$ \\ Loyola College
}

\begin{abstract}
India is an agrarian country and agriculture is the principal means of livelihood for more than half of its population. According to the recent Indian National Sample Survey ${ }^{2}$, there are 90.2 million agricultural households in rural India, which is 57.8 per cent of the total estimated rural households (156.1 million) in the country. For these farming communities, agricultural market is the backbone. Markets tend to marginalize small farmers for lack of assets, want of adequate quality and quantity of assets, and finally the inner dynamics of market itself. If the market marginalizes the farmers, the farmers have no choice but to leave farming or leave this world. The consequent outcome of this situation will be alarming for a country and it may impose socio-economic and political crisis that can adversely affect the business environment of a country. However, India also has stories of valiant fight against this marginalization of small farmers. This paper is an outcome of an ethnographic study to understand the process of marginalization of small farmers in the market. It elucidates some of the strategies these farming communities have developed in managing the markets. The study narrates the successful grassroots story of managing markets in a creative manner.
\end{abstract}

\section{INTRODUCTION}

India is an agrarian country and agriculture is the principal means of livelihood for more than half of its population. As per 2011 census report, agriculture is the largest private-sector enterprise in India, engaging nearly 119 million farmers (cultivators) and another 144 million landless laborers (Domodaran, 2016). National Sample Survey ${ }^{3}$ reported that there are 90.2 million agricultural households in rural India and among them 75.42 per cent are marginal farmers operating land size of 0.002 to 1.0 hectare only . According to the World Fact Book of the Central Intelligence Agency (CIA) for 2014, the global agricultural output stands at $\$ 4,771$ billion and 42 percent of this comes from just six countries. Among the six countries, China tops the list with the contribution of $\$ 1,005$ billion and India is the second largest producer with $\$ 367$ billion. In fact, China and India alone account for close to 30 percent of the global total. Gross Domestic Product (GDP) of agriculture and allied sectors in India were recorded as US\$ 244.74 billion during the Financial Year (FY16). All these show that agriculture in India is a vital sector with enormous potential for growth. 


\section{Size of Agricultural Market in India}

As per the estimate of India Brand Equity Foundation, India is the largest producer of spices, pulses, milk, tea, cashew and jute; and the second largest producer of wheat, rice, fruits, vegetables, sugarcane, cotton and oilseeds. Further, India stands second in global production of fruits and vegetables, and is the largest producer of mango and banana. It also has the highest productivity of grapes in the world. India is the largest producer, consumer and exporter of spices and spice products. India's horticulture output was estimated to be 287.3 million tonnes (MT) in 2016-17 after the first advance estimate. It ranks third in farm and agriculture outputs. Agricultural export constitutes 10 per cent of the country's exports and is the fourth-largest export of the principal commodity.

\section{Agricultural Growth Story}

According to the Indian Business Standard news report, between 1970-90 India's agricultural GDP grew from $\$ 25$ billion to $\$ 101$ billion registering an absolute growth of $\$ 76$ billion. However, in the next 14 years from 2000 to 2014, it leaped from $\$ 101$ billion to $\$ 367$ billion, registering an astonishing growth of $\$ 266$ billion. Evidently the growth in agriculture during the last 14 years was 350 percent higher than what was achieved in the previous 30 years. It is indeed an impressive growth and holds enormous promise for the future. The analysis also revealed that the contribution to this impressive growth was from three high-value segments, i.e. dairy, horticulture and inland fisheries. The same news item observed that India's international trade in agricultural products fetches higher earnings for the country than trade in services or manufacturing. The team argues that India's small-sized family farms practice, a unique kind of mixed agri-horti-livestock farming, is a cost-effective model which is ideal for other developing nations with small farms. Indian farmers practice multitasks, and shift with ease from crop cultivation to animal husbandry, thereby remaining engaged throughout the year. This versatility has transformed the Indian agricultural sector into a global leader.

\section{Marginalization in Markets}

The size of the agricultural market and its global significance failed to benefit the large majority of small and marginal farmers in India. Markets have been alien to small and marginal farmers due to their scale of operation, paucity of ready cash, lack of knowledge of market dynamics and above all absence of quality consciousness. As a result, both the input as well as output markets excluded them. Liberalization accentuated this exclusion and failed to insulate them from the vagaries of the market dynamics. First of all, green revolution introduced high yielding variety seeds along with cash crops to increase the income of household. This naturally profited the rich more than the resource poor farmers (Byres, 1981; Reddy and Mishra, 2010). Secondly the neo-liberal regime lifted export restrictions and promoted entry of multinational corporations that encouraged farmers to shift from traditional crops like rice, wheat, pulses, etc. to cash crops like cotton, potato, tomato, etc. In spite of this shift in the crop pattern, they still enter the market as weak players. d'Orfeuil (2012) speaking for small and marginal farmers in developing countries raised these questions:

"How can farmers with little equipment and land, barely supported by public policies, deprived of support in terms of research, training and information, often living in areas where the climate is difficult and soils are degraded, fight against producers who have all the advantages? The competition resulting from market opening is untenable for the weakest competitors and condemns them to withdraw from markets, and even from farming. Moreover, market opening is accompanied by the enforcement and strengthening of standards - particularly health standards - that are difficult to meet for small-scale farming. The standards impede small farmers from accessing northern markets, and even sometimes the urban markets of their own countries."

Moreover, introduction of Genetically Modified (GM) crops along with the high-value but high-risk hybrid crops exposed them to very high level of market dependence. The change of cropping pattern forced the small and marginal farmers to depend on the Multi-National Companies (MNCs) for seed, 
fertilizer, pesticide, credit, etc. which essentially worked for their own profit than for wellbeing of the farmers. Many cases of farmer suicides in India show a link between suicide and multinational company that supplied seed and pesticide (Shiva et al, 1999). As of today, every input a farmer requires is in the hands of the MNCs.

\section{Objectives of the Study}

The following are three major objectives of this ethnographic study:

1. To analyze the dynamics of market marginalization.

2. To elucidate the relationship between human capital formation and managing market marginalization.

3. To document the models of market management.

\section{Methodology}

This ethnographic study was undertaken in three districts of Tamilnadu, India. Dindigul, Madurai and Theni are neighboring districts located in southern India where Commonwealth of Learning has been working among farmers since 2000. Attending their monthly meetings, facilitating their various training programs and the longitudinal studies was the source of primary data for the study. There were also four impact studies undertaken by my external bodies to assess the outcome of Lifelong Learning introduced among farmers. Those studies also provided scientific data for this study.

\section{Dynamics of Market Exclusion}

Markets have their own inherent dynamics of exclusion that is built into the present day market economy. Deepak Nayyar (1998) argued that market is central to economy and that is where goods and services are bought and sold. Since the very nature of economy had turned out to be market-led from the time of neo-classical economics, participation in market is determined by one's capacity to either sell something or buy something. A farmer brings his produce to the market and a consumer buys the produce for consumption. This implies that the farmer has his produce, say his vegetables, to sell and the consumer has money to buy it. The possession of vegetables enables the farmer to enter into the market and the possession of money enables the consumer to enter into the market. This is the first and fundamental condition for participating in a market. This implies that the dynamics of market is that one needs to be endowed with some assets to get included into the market (Nayyar, 1998). The asset may be one's goods or services, money, capabilities, resources, etc. Lack of endowment means lack of inclusion in the market. Consequently, the people who are not endowed with assets will get excluded from the market.

Secondly, endowment alone does not guarantee an entry into market. The endowment must be, first of all, marketable or able to fetch a price. For example, one may have vegetables but it must be marketable, either in terms of its use value or because of its rarity. Certain goods and services become redundant in the market because of not having any demand or due to their non-usability and abundance in supply. Here, the focus is not only on availability but also on quality as well as utility. An asset or capability may get excluded from the market because of its poor quality or inability to match the present need. Excessive supply of unskilled labor force in developing countries and the agricultural produce of small holding population are typical example for this category of exclusion.

Thirdly, exclusion may also happen due to rules and regulations of the market. Market by its very nature has its own rules and regulations, which are initially determined by the participants. Rules for buying, selling and quality parameters are some of them. However, as the trading begins and the market starts functioning, it brings its own dynamics, rules and regulations. In this very dynamics, some become the winners and some become the losers. This cycle of winning and losing eventually eliminates a large majority of them. This is where the unemployed, small farmers and manufacturers of small scale industries lose. 
Adding to these is the lack of supportive environment, d'Orfeuil (2012) spoke about in his study on small and marginal farmers. Supportive policy environment is central to any sector that enters a competitive market with unequal endowments. Small and marginal farmers need to be insulated from multiple risks when they enter the global markets with weak endowments. For example, in the case of contract farming, the farmer may face serious risk in the absence of policy environment. The study of Chakrabarti (2015) quoting the works of Shojarani 2007, Kumar and Kumar 2008, Swain et al 2012, Lavanya and Rathnakar 2014, highlighted the challenges involved in contract farming. These studies indicated that in the absence of adequate support system, the farmers get excluded from the markets. Figure-1 pictorially portrays the dynamics of market exclusion in the present context. All the four factors play a strong role in excluding small and marginal farmers.

The small and marginal farmers in rural India with insecure livelihood resources remain marginalized from the market as well as from the fruits of development. This dynamics of exclusion that is embedded in the present day economy is endogenous and endemic. It is to be underscored that the exclusion from the market has its impact on other domains too. Nayyar (1998) elaborated the impact of economic exclusion on social, political and cultural domains and concluded, "Economic exclusion exacerbates other forms of exclusion" for the farmers.

FIGURE 1

\section{EXCLUSION BY MARKETS MANAGING MARGINALIZATION}

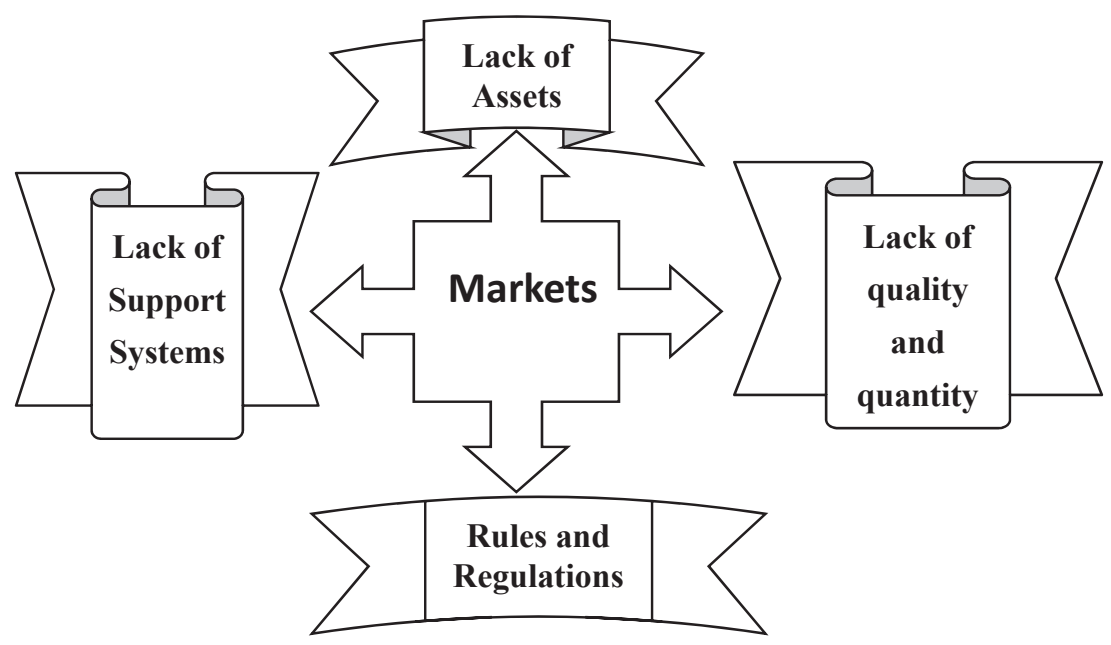

Small and marginal farmers' marginalization is on the increase due to socio-economic and geographical reasons, and, at the same time, farming communities also come up with innovative solutions to manage market marginalization. Development personnels, policy makers and grassroot level community-based organizations have come together to confront this market marginalization. An ethnographic study of farming communities in three districts of Tamilnadu, India has revealed that farming communities can be trained to handle market marginalization in a creative way and to harness the potentials the emerging markets offer them. The following pages highlight the strategies adopted by the farming communities in rural India. 


\section{Investment in Human Capital Formation}

Life Long Learning for farmers (L3F) was a new initiative of Commonwealth of Learning (CoL) to promote development among farmers in rural areas through Open and Distance Learning (ODL). CoL firmly believes that inadequate human resource development among millions of farmer families in many Commonwealth countries has been one of the major causes for the livelihood insecurity and inability to tap market opportunities. Consequently, need based learning, covering their entire socio-economic value chain, founded on the principle of ODL with the help of modern Information and Communication Technology (ICT) tools can transform lives of deprived communities. Providing learning opportunities through conventional mode is impossible keeping in view the size of the learners as well as the diversity of their learning needs (Thamizoli et al, 2011; Kumar and Anjali, 2013). As a result, CoL tapped the modern ICT tools to expand learning both for the learners as well as for the trainers. L3F educates, organizes and thus empowers vulnerable rural women and their families to gain knowledge, create their own self-directed learning process, organize themselves to solve problems of marketing their products and food security, improve their living conditions, and increase their freedom and independence from government support (Rosemary, 2013).

The L3F approach is based on the realization that farming communities, through their own community knowledge system and different forms of social capital, develop their own value-added farming, encourage more sustainable use of natural resources, strengthen their ability to handle markets and ensure food and livelihood security. It is argued that when individuals are endowed with assets like knowledge capital and social capital they begin to interact better in a given opportunity.

\section{Process}

L3F achieved this process of transformation through three fold strategy. The first strategy is formation of small groups in the local community, which plays a pivotal role in the entire process. This small group meets on a regular basis and these meetings provide platforms for learning, building strong cognitive social capital, fostering group solidarity, and above all, creating a sense belonging to a community. The next stage is introduction of horizontal and vertical learning with the help of ICTs. In many of the interventions, mobile phones are used to send voice SMS (Short Message Services) at periodic intervals on a theme decided by the people, in their own dialect and in their own voices. Apart from this, they also invite knowledge experts to strengthen their learning process. In this whole process, the approach is bottom-up and participatory while constantly gathering feedback to fine tune the learning process. Thirdly, group formation and self-directed learning empowers them to enter into negotiations with institutions that affect their lives like banks, input suppliers, internal and external markets, agricultural and veterinary universities, government officials like collectors and extension officials, etc. Equipped with the knowledge of their economic activity, empowered by their social solidarity, the small and marginal farmers enter into negotiations with banks for their much needed credit; District Collectorates for timely supply of agricultural inputs; knowledge repository for timely information; and markets for the best price for their produce. This process begins to transform their socio-economic life through transforming the institutions that shape their lives, and achieves their inclusion in domains where they were excluded.

\section{Outcomes of L3F- Expanded Mobilization}

Initially, in all three districts, the farmers were mobilized as small groups and horizontal and vertical learning was introduced. However, this group formation did not enable them to handle markets. Mobilizing farmers as producers and collectivizing these producers as company produced a possibility with the incorporation of a new Part into the Indian Companies Act 1956. This amendment was introduced in 2003 and this paved the way for the formation of Farmer Producer Organization (FPO). The following are the essential features of a FPO: 
1. It is formed by a group of producers for either farm or non-farm activities.

2. It is a registered body and a legal entity.

3. Producers are shareholders in the organization.

4. It deals with business activities related to the primary produce/product.

5. It works for the benefit of the member producers.

6. A part of the profit is shared amongst the producers.

7. Rest of the surplus is added to its owned funds for business expansion.

Consequently, the farmers who were part of Lifelong Learning came forward to form themselves as Farmer's Producer Organisation (FPOs); namely Reddiarchatram Sustainable Farmer Producer Company Limited (RSFPCL) formed in 2010 in Dindigul District, Theni District Farmers Goat Producer Company Limited (TDFGPCL) started in 2013 in Theni District and Madurai Maavatta Thennai Mattrum Ethra Payirgal Producer Company Limited (MMTMEPPCL) in 2016 in Madurai District. FPO came as big boon for the small farmers as this formation gave them numerical strength and reasonable financial resource; increased cognitive and structural social capital; and expanded their knowledge capital. Armed with increased access to socio-financial and knowledge capital, the three producer companies are successfully managing marginalization of market through a three pronged approach.

\section{Multiple Models of Market Management}

The newly found mobilization gave the small and marginal farmers multiple opportunities to manage market marginalization. Although the models are not new but the models do offer the small and marginal farmers advantages that were alien to them. So far the FPOs have been successfully launched and achieved success through a process of aggregation and value addition models. They are growing stronger in these two domains. Apart from this, they are also working on e-market portal to launch into e-commerce.

Aggregation: Small and marginal farmers do not produce large quantities and their marketable surplus tends to be minimal. This automatically excludes them from the market. Consequently, the producer companies buy the marketable surplus from the farmers and aggregate them for the wholesale market. While RSFPCL aggregates maize from the farmers, TDFGPCL aggregates goats from the farmers and the MMTMEPPCL aggregates coconuts from the farmers. This aggregation enables them to store larger quantity of agricultural commodities, bargain better price, avoid distressed sale and protect farmers from middle men.

Value Addition: Value addition is an important marketing mechanism to reach the end users with the better price. In the agrarian supply chain, value addition bridged the gap between the producers and the consumers. When this task is undertaken by the farmers themselves, the entire benefit of value addition accrues to the farmers themselves. MMTMEPPCL does this in the coconut market. When they get good quality coconuts, they extract coconut oil and sell it to the consumers, consequently increasing their income.

\section{E-Marketing}

In the globalized market, E-marketing offers enormous potential for the farmers. Apart from providing access to global market, e-market also removes intermediaries. Currently, CoL is helping the farmers equip themselves to handle e-market opportunities. More than technological part, the preparedness of farmers to enter into e-commerce calls for whole range preparation spanning various fields like financial literacy etc. In all these, the basic approach is the contemplated new initiative is to feel need of the people which it should be bottom-up. Only then it will become sustainable and people centric. 


\section{Business Potentials of FPOs}

Farmers Producers Organizations (FPOs) are here to stay and they do offer new hope to the small and marginal farmers to manage market marginalization as well as their socio-economic problems. . It is also equally true that FPOs have opened up possibilities for the agribusiness as an industry. First of all, the collectivization of small and marginal farmers as Farmer Producer organization is expanding their bargaining power. Added to this, several FPOs are coming together as federations and these in turn are entering into partnership with federations of other states to demonstrate the power of collectivization. This would not only enable companies to learn from each other, share technical inputs but also market products to different states. Thirdly, elimination of intermediaries boosts the profitability of the farmers as well as the agribusinesses.

\section{CONCLUSION}

In India, small and marginal farmers make the bulk of producers and their contribution to the agriculture market is substantial, but, scattered. Lack of knowledge capital brought in intermediaries of different kinds in all walks of their lives, including markets. Empowering them through Lifelong Learning enables them to organize themselves and manage problems that surmount for a long time. Moreover, this process has opened up new possibilities for agribusiness companies to enter into negotiations with FPOs for a win-win situation. Consequently, governments and agribusiness companies can invest part of their resources in empowering farmers for their own sustainable business opportunities.

\section{ENDNOTES}

1. Department of Sociology, Loyola College, Chennai, Tamil Nadu, India

2. email: thomamir@gmail.com

Key Indicators of Land and Livestock in India. NSS 70th Round 2013, NSS KI (70/18.1)

3. ibid 


\section{REFERENCES}

Agriculture in India. "Information about Indian Agriculture and its Importance." Accessed May 15, 2017. https://www.ibef.org/industry/agriculture-india.aspx.

Atieno, Rosemary. 2013. "Life Long Learning for Farmers (L3F) Initiative Implemented in Kenya and Uganda." Accessed April09, 2016. http://oasis.col.org/handle/11599/580.

Byres, T.J. 1981. "The New Technology, Class Formation and Class Action in the Indian Countryside." Journal of Peasant Studies 8 (4): 405-454.

Chakrabarti Manas. 2015. “An Empirical Study On Contract Farming In India.” International Journal of Informative \& Futuristic Research, Volume 2 Issue 5 January. Accessed May 20, 2016. http://ijifr.com/pdfsave/03-02-2015855V2-E5-017.pdf.

Harish Damodaran. 2016. "Is Agriculture a Business?'Indian Express,(April 1, 2016.) Accessed May 14,2017.http:/indianexpress.com/article/opinion/columns/india-agriculture-sector-a-business/.

Henri Rouillé d'Orfeuil. 2012. "The Exclusion of Farmers: A Historical Challenge for the International Labour Market." Accessed August 13, 2016. http://sapiens.revues.org/1487.

Kumar J. \& Kumar P.K. 2008. "Contract Farming: Problems, Prospects and its Effect on Income and Employment." Agricultural Economics Research Review 21: 243- 250.

Kumar K Naveen \& Anjali Kulkarni. 2013. "Investment by Commercial Banks in Training Rural Communities and its Impact: Scope of Open and Distance Learning." National Institute of Bank Management and Commonwealth of Learning. Accessed March 20, 2015.http://oasis.col.org/bitstream/handle/11599/214/InvestmentsCommercialBanks_Rural.pdf?s equence $=1 \&$ isAllowed $=\mathrm{y}$.

Lavanya K.V.A. \& Rathnakar S. 2014. "Contract Farming Need of the Hour." The Management Accountant November 2014: $26-30$.

Nayyar, Deepak. 1998. "Economic Development and Political Democracy - Interaction of Economics and Politics in Independent India."Economic and Political Weekly 33 (49), 05 Dec, 1998:3121-3131.

Reddy, Narasimha \& Srijit Mishra. 2004. "Economic Reforms, Small Farmer Economy and Agrarian Crisis." In Agrarian Crisis and Farmers Suicide, edited by Deshpande and Saroj Arora. Sage, New Delhi.

Shiva, Vandana, Ashok Emani, \&Afsar H. Jafri. 1999. "Globalization and Threat to Seed Security: Case of Transgenic Cotton Trials in India." Economic and Political Weekly 34 (10/11) (Mar. 6-19): 601-613.

Shojarani, B.N. 2007. "Globalization and Contract Farming in India-Advantages and Problems." Accessed March 18, 2017.

http://v-reform.org/wp-content/uploads/2012/08/globalization-and-cf-advantage-and-problems.

Swain P.K., Kumar C. \& Raj Kumar C.P. 2012. "Corporate Farming vis-a-vis Contract farming in India: A critical perspective." International Journal of Management and Social Science Research 1(3) 60-70. Accessed February 12, 2017. http://www.irjcjournals.org/ijmssr/dec2012/12.pdf.

Thamizoli, Henri Francis, Hilaria Soundari, Balasubramanian \& Kamaraj. 2011. "Learning for Farming Initiative: Longitudinal Study Tracing the Lifelong Learning for Farmers Activities in Tamil

Nadu,India,2011.” Accessed March 20, 2015. http://oasis.col.org/bitstream/handle/11599/579/L3F\%20Evaluation\%20Study\%20India\%20\%20 2011.pdf? sequence $=1$ \&isAllowed $=\mathrm{y}$. 